\title{
Evaluating opportunities for successful public-private partnership in the healthcare sector in Poland
}

\author{
Ewa Agnieszka Kosycarz ${ }^{1}$ - Beata Anna Nowakowska ${ }^{2} \cdot$ Marcin Mateusz Mikołajczyk $^{1}$
}

Received: 23 January 2018 / Accepted: 11 April 2018 / Published online: 23 April 2018

(C) The Author(s) 2018

\begin{abstract}
Background The aim of this study is to analyse and assess barriers and opportunities for the improvement of the condition of public hospitals in Poland by means of public-private partnerships.

Methods The study reviews the literature and acts concerning this subject, and undertakes exploratory analyses of data acquired from national health data repositories.

Results The situation of healthcare system in Poland is complex. There are several opportunities for alternative collaboration between private and public sector, such as joint shareholding by private and public partners in a hospital. However, there are significant barriers for developing PPPs, such as short-term contracts with public payers and a very low level of funding for health care services.

Conclusions Examination of different models of PPPs in different countries suggest that several important factors are required for a successful PPP project. The main factors that may affect the success of PPPs in the Polish market are: changes to the contract with the payer for the health care services, stable economic and legal conditions, appropriate allocation of risk, enough experience on both sides, use of a reputable and competent private partner, and sufficient initial capital.
\end{abstract}

Keywords Public-private partnership (PPP) · Healthcare system · Public hospital · Healthcare system reforms in Poland · Healthcare financing

JEL Classification H51 - Government Expenditures and Health · I11 - Analysis of Health Care Markets.

Key Points - Total expenditure on the healthcare sector in Poland in 2015 was $6.3 \%$ of GDP. More than one third of all financial resources dedicated to health care in Poland are consumed by hospital care. This is half of public funds.

- In hospital care in Poland, there has been cooperation between the public and private sectors for a long time.

- Until now, the private sector was able to buy hospitals from public entities, so this might have caused less interest in PPP formula.

- The Ministry of Finance and the Ministry of Development in Poland support the PPP formula for public sector investment.

Ewa Agnieszka Kosycarz

ewa.kosycarz@sgh.waw.pl

Beata Anna Nowakowska

beata.nowakowska@imid.med.pl

Marcin Mateusz Mikołajczyk

marcin.mikolajczyk@sgh.waw.pl

1 Collegium of Socio-Economics, Warsaw School of Economics, Al. Niepodległości 162, 02-554 Warsaw, Poland

2 Department of Medical Genetics, Cytogenetics, Institute of Mother and Child, Warsaw, Poland

\section{Introduction}

All governments worldwide struggle with rising health care expenditures and public budget constraints. This factor has led governments to look for various approaches to limit their costs and increase investment in the health sector via public-private partnerships (PPP). PPPs are increasingly seen to improve the performance of health systems worldwide, by bringing together the best characteristics of the public and private sectors to improve efficiency, quality, and innovation (Mitchell 2003).

\section{What is PPP in public health}

Introduced for the first time in 1990, a public-private partnership is an agreement between one or more public and private entities, typically of a long-term nature, reflecting mutual responsibilities in furtherance of shared interests. The importance of that definition is that PPPs work only when both partners benefit from the relationship, and the expected benefits are made clear in advance (Mitchell 2003). The most 
common reason for the development of PPP is financial. This might take the form of increasing resources or through cost reduction. For the private companies, the financial mechanisms can be direct or indirect, but for the public hospitals, re-constructing and innovative ways of managing in general should help control costs and improve hospital services. If properly formulated and managed, PPP can provide a number of benefits to the public healthcare sector, and two of the most important seem to be reducing the financial burden on the public sector for infrastructure development, and risksharing between partners (Kwak et al. 2009). By implementing some of the principles of the private sector, PPP could change the perception of public hospitals. Therefore, PPPs are considered more as an instrument to improve value for money than an additional source of financing (Espigares and Torres 2015).

In addition to the benefits for a private partner and public hospital which participates in PPP, central and local governments can also benefit. The money allocated to the development of a public hospital is not included in the debt and deficit of general government (according to Eurostat decision no 18/ 2004). The same mechanism also applies to governments in New Zealand, Australia, Canada, and the USA (Hall 2015).

Based on different degrees of responsibility and risk, nine different models for private participation in public hospitals have been proposed by Taylor and Blair (2002). Table 1 presents the most commonly used PPP variants in healthcare sector (Taylor et al. 2002; Mckee et al. 2006).

\section{PPP in healthcare worldwide}

PPPs have been used in several countries to reform the healthcare sector constructively. In both developing and undeveloped countries, public-private partnerships have been commonly used to spur and facilitate innovations in a number of healthcare fields. The most common activities relate to research in general, vaccines and discovery of drugs for the treatment of communicable diseases, development of personalized medicine, and management and infrastructure growth (Kwak et al. 2009; Reijneveld 2012; Gottwald et al. 2016; Karawajczyk et al. 2017; Granados Moreno et al. 2017; Sadeghi et al. 2016a, b). But the biggest emotions and controversy concern the partnerships with public hospitals.

In general, even in countries which have signed the most contracts, such as the UK and Australia, PPPs account only for about $15 \%$ of all infrastructure investments in all sectors. For most OECD countries, the proportion is less than 5\%, but in many still close to zero. Within Europe, PPPs represent little more than 5\% (EIB 2012). The European PPP Expertise Centre reported that in 2016 the aggregated value of all kinds of PPP transactions in the European Market (defined as EU28, Western Balkans, and Turkey) reached EUR 12 billion, and exceeded the value from 2015 by $22 \%$. Looking at the healthcare sector, the number of projects that reached financial conclusion increased to 15 , and the aggregate contracted value significantly, to EUR 2.3 billion.

Examination of different experiences of different models of PPP in various countries indicates the legal, cultural, and social influences which are of great importance in the success of the partnerships.

It is widely believed that the maximization of profits by a private investor taking over a public hospital will adversely affect the patients for whom the hospital should provide free services. An example of a rejection of this theory is Brazil, where the number of treated patients increased by $30 \%$ after the introduction of a private operator in 12 new public hospitals, constructed and financed by the government (Taylor et al. 2002). Another example that shows the benefits of taking over a public hospital by a private operator is St. Goran's hospital in Stockholm, Sweden. The private operator has not only

Table 1 Commonly used model of PPP in healthcare sector

\begin{tabular}{|c|c|c|}
\hline Option & Private sector & Public sector \\
\hline Outsource services & $\begin{array}{l}\text { Provides services; only nonclinical, only clinical } \\
\text { (like specialized procedures) or both - clinical } \\
\text { and nonclinical. }\end{array}$ & Manages hospital. \\
\hline Operate & $\begin{array}{l}\text { Manages hospital under contract with government } \\
\text { or public insurance. }\end{array}$ & Pays private operator for provided services. \\
\hline Build-own-operate & $\begin{array}{l}\text { Finances, constructs and operates hospital with or } \\
\text { without medical service }\end{array}$ & $\begin{array}{l}\text { Reimburses for capital costs, provide medical service } \\
\text { or pays private operator for provided services. }\end{array}$ \\
\hline Build-own-leaseback & Finances, constructs and lease it back to government & $\begin{array}{l}\text { Manages hospital and pays lease installments. } \\
\text { Provides medical service. }\end{array}$ \\
\hline Own private part within public hospital & Operates private wing for private patients. & $\begin{array}{l}\text { Manages hospital, but shares costs, staff and equipment } \\
\text { with private part. }\end{array}$ \\
\hline Purchase public hospital & $\begin{array}{l}\text { Purchases facility and operates under contract } \\
\text { with government. }\end{array}$ & Pays private operator for provided services. \\
\hline
\end{tabular}

Source: Table adapted from [Taylor and Blair 2002; McKee et al. 2006] 
improved the quality of service, but also the hospital is now able to treat 100,000 more patients annually with the same resources (Hjertqvist 2000). McKee and co-authors (2006) pointed out, based on the experience of countries such as Australia, Spain, and the UK, that new facilities created by PPPs have been more expensive than they would be when produced with the conventional system. But first, they are usually built on time, and second, with the traditional method, new facilities often entail compromises on quality. McKee and co-authors (2006) reported that in 2001, $76 \%$ of PPP projects in the UK were delivered on time and $79 \%$ within the planned budget, compared with $30 \%$ on time and $27 \%$ within budget using conventional procurement.

In October 2011, the European Agency for Health and Consumers launched a tender for conducting the Health and Economic Analysis for an Evaluation of PPP in Health Care Delivery across EU. The consultants provided their report based on studies from different countries in August 2013 (EXPH 2014). The aim of this study was to review the value-formoney results and analyses undertaken by public authorities in procuring and managing PPP contracts in the health sector. The study intended to add valuable transparency and clarity to public spending and contingent liabilities in healthcare PPPs. However, reliable evidence about the nature of contracts and performance of PPPs is limited due to the confidential character of business relationships between the public and private sectors. The conclusion was that is very difficult to compare the financial benefits of PPP contracts with the traditional forms of fundraising.

However, the experience of PPPs are not always positive. Kwak and co-authors (2009) pointed out three main success factors for PPPs: competence of the government, selection of an appropriate private partner, and appropriate risk allocation between partners. They also pointed out factors due to which many PPP projects are terminated: "wide gaps between public and private sector expectations; lack of clear government objectives and commitment; complex decision making; poorly defined sector policies; inadequate legal/regulatory frameworks; poor risk management; low credibility of government policies; inadequate domestic capital markets; lack of mechanisms to attract long-term finance from private sources at affordable rates; poor transparency; and lack of competition."

\section{Methods}

The study reviews the literature, and undertakes exploratory analyses of data acquired from national health data repositories. Acts related to the cooperation between private and public sector were analysed. The study also reviews the information with regard to recent and planned changes in healthcare systems and the law of public-private cooperation. It was obtained from newspapers, speeches at the conferences, and ministry websites.

\section{Results}

\section{Public hospitals in Poland}

Total (public and private) expenditure on the healthcare sector in Poland in 2015 was $6.3 \%$ of GDP. Of the 34 countries monitored by the OECD, only Turkey, Latvia, Mexico, and Luxembourg spent a lower percentage, and their expenditures accounted for approximately $6 \%$ of GDP.

More than one third of all financial resources dedicated to health care in Poland are consumed by hospital care. This is half of public funds. Hospital care is the health sector that is struggling with the greatest financial difficulties. The biggest problem faced by public hospitals is the problem of debt build-up. This is a problem that has long been known in the Polish health system. However, as yet it is unresolved.

An important step in reducing public hospital debt was taken on 27 April 2009. The Council of Ministers adopted a resolution to launch a multi-annual program Support for local government units in stabilization.(Uchwała $\mathrm{Nr} 58 / 2009)$ The program was aimed at reducing the SPZOZs (SPZOZ — Independent Public Health Care Unit) debt by transforming SPZOZs into capital companies. It was recognized that in such a form these units would be much more functional. This decision was taken after analysing 71 examples of hospitals (mainly at powiat - county or district - level) transformed between 1999 and 2008. This was a step towards greater cooperation between the public and private sectors in health care.

2011 was a time of successive changes in the healthcare system aimed at introducing market mechanisms into the healthcare system, encouraging the transformation of hospitals into capital companies, and maintaining the possibility of them being acquired (even 100\%) by private partners.

In the context of the high level of hospital indebtedness in Poland and the debt of the general government sector, hospital PPPs should be considered by the authorities as a source of funding for an investment which helps to maintain control over the delivery of public services. It is important that in Polish financial law there is an additional fiscal rule that limits the level of debt of local government, who own the majority of public hospitals. Over the period of the previous European budget, EU funds increased the indebtedness of local government units as a result of them contributing their own funds to EU projects. This situation may result, along with the high demand for hospital investments, in an increase in interest in the PPP formula (Herbst and Jadach-Sepioło 2012, 2014). However, the interest of the public sector itself is not sufficient. The private sector must see the real benefits of cooperation. The most important factor in the poor financial situation of the Polish hospital system is the very limited revenue and the high cost of providing medical services (Magellan 2014a, b).

The financial situation of the Polish authorities should have prompted a full PPP model, including hospital management 
and the provision of medical services. As in other countries, investment expenditure accounts for only about $5 \%$ of all health expenditure ( $\mathrm{PwC} 2010)$. However, as has already been mentioned, the biggest problem lies in the level of funding for medical services.

Among the causes of the current situation of public hospitals in Poland, several other factors can be distinguished. First, the contracts between hospitals and the National Health Fund (NFZ), payer for medical procedures, are renegotiated usually every 3 years, with no guarantee that after 3 years the contract will be extended, and with no guarantee of future prices. In practice, as a consequence, hospitals accept prices offered by NFZ which are very often inadequate to cover costs of procedures. Second, which is also a consequence of the first factor, excessive use of hospital treatment. While in Western Europe it is common to avoid multi-day hospitalization, in Poland, leaving patients in the hospital is a way to cover the costs for diagnostics, because hospital diagnostics are priced higher than outpatient treatment. Third, Poland, like many countries in Eastern Europe, has too many public hospitals. As a result, Poland has over six hospital beds per thousand inhabitants, which is one of the highest rates in Europe (Deloitte 2016). Further reason for debt is an outdated infrastructure, which not only causes maintenance expenses, but also increases operating costs.

The current Polish government has announced several key health care reforms to improve the condition of public hospitals. One of them is the formation of a network of hospitals.

According to the announced regulations, less than $2 / 3$ of all hospitals (594 before the appeals process) were placed in the network. Hospitals had to meet some requirements to be classified as a network entity. These requirements ensure that the largest and most multifunctional units were included in the network. Two-thirds of hospitals does not mean $2 / 3$ of all hospital beds, but many more. The Ministry of Health estimates that $93 \%$ of NFZ funds which have so far been targeted on hospital treatment will be allocated to the hospitals network. The remaining $7 \%$ will be spent on medical contracts with hospitals, as so far (out-of-network hospitals as well as out-of-network medical services offered by network hospitals). The purpose of the reform, as reported by the Ministry of Health, was to ensure financial stability in hospitals (the list of hospitals covered by a lump sum will be verified every 4 years) and the introduction of coordinated care for patients. On the occasion of the reform, there are already some additional effects: some of the hospitals needed to meet the requirements of the network have merged with others. This applies both to public and private entities.

In addition, from 2018, the quality will be taken into account in the lump sum calculation algorithm. In the immediate future, it will be verified by obtaining quality certificates. Plans for the future are to prepare and use a quality monitoring system (indicators). The algorithm is planned to include a premium for implementing more ambulatory medical procedures. This should result in shortening the patient's stay in hospital. The proposed funding structure can foster longterm engagement of private actors, which as shown by studies are more efficient (PwC 2010).

In addition, the government plans to increase public spending on healthcare up to $6 \%$ of GDP; in 2015 it was $4.7 \%$ according to Eurostat data.

\section{PPPs in Polish healthcare}

In Poland, PPP co-operation is mainly based on three laws: the Public Procurement Act, the Public-Private Partnership Act, and the Act on Concession for Works or Services. The differences resulting from the applied act in the PPP cooperation model (the Public-Private Partnership Act or the Act on Concession for Works or Services) concern the following areas:

- Remuneration of a private partner

- Risk distribution

- Obligations of both parties to the contract

- Asset allocation after contract termination

- Possibility of creating a special purpose entity for the implementation of the PPP project

- Contract duration

- Requirements for approval of Minister of Finance (Gajos 2014).

In the recent period, all of these acts have changed to facilitate the PPP contracting process. The changes introduced are positively evaluated as making PPP contracts more flexible. However, lawyers dealing with this subject indicate additional issues that should still be considered and resolved in the acts (Wawrzyniak 2016).

Up to now, projects implemented on the basis of the PPP model have been implemented on the both acts: the PublicPrivate Partnership, and the Act on the Concession Agreement for Works or Services. Table 2 presents all the previously signed and implemented cooperation agreements of the PPP form in Poland in the area of healthcare (www.ppp.gov.pl, Forum PPP 1(31) 2016, www.pppportal.pl).

Although there has been increasing attention to PPP, and the number of signed contracts is growing, successful partnerships can be seen in all areas of the economy outside of healthcare.

The Public-Private Platform website is a comprehensive review on public-private projects which are planned and already signed. It includes information on the distribution of PPPs, project types, investments, and prospects of success (www. ppp.gov.pl). According to the report published by the Polish Agency for Enterprise Development, during the years 20092016 the total number of concluded PPP contracts in all sectors in Poland was 112, while the number of all proceedings initiated was 470 . The sectors of greatest interest to public entities were sport and tourism. The largest number of PPPs 
Table 2 All signed and implemented cooperation agreements in the PPP form in Poland in the area of healthcare

Design, manufacture, and equipping of installations and media and equipment for the facility

at SP ZOZ of the Multidisciplinary Hospital in Jaworzno with the purpose of a bed nephrological unit

Legal form: The Act on Concession for Works or Services

Model of cooperation: Design-build-operate-transfer

Risk distribution:

Demand, construction, availability risk: private partner

Form of remuneration of private partner: fees from users

The date of conclusion of the contract: 31.03 .2010

Value: PLN 1,500,000

Duration: 180 months

Reconstruction of the Social Care Center in Kobylnica for the needs of the Department of Caring and Treatment

Legal form: The Act on Concession for Works or Services

Model of cooperation: Build-operate-transfer

Risk distribution:

Demand, construction, availability risk: private partner

Risk and responsibility of public partner: correctness of the project documentation submitted to the private partner; establishment of a mortgage on a property of $75 \%$ of the collateral of a private partner loan

Form of remuneration of private partner: fees from users

The date of conclusion of the contract: 5.10 .2010

Value: PLN 4,295,128

Duration: 360 months

Construction of the District Hospital in Zywiec

Legal form: The Public-Private Partnership Act

Model of cooperation: Design-build-finance-maintain

Risk distribution:

Demand risk: private and public partner

Construction, availability risk: private partner

Form of remuneration of private partner: The remuneration will depend on the actual availability and actual use of the new hospital

The date of conclusion of the contract: 15.11.2011

Value: PLN 138,779,931

Duration: 360 months

Designing, constructing and equipping necessary hospital facilities at the Multidisciplinary Hospital in

Jaworzno for the dialysis station and the nephrological clinic

Legal form: The Act on Concession for Works or Services

Model of cooperation: Design-build-operate-transfer

Risk distribution:

Demand, construction, availability risk: private partner

Form of remuneration of private partner: fees from users

The date of conclusion of the contract: 06.08.2009

Value: PLN 6,222,000

Duration: 180 months

Set up a Radiotherapy Center

Legal form: The Act on Concession for Works or Services

Risk distribution:

Demand risk: public partner

Construction and availability risk: private partner

Form of remuneration of private partner: fees from users

The date of conclusion of the contract: 29.05.2013

Value: PLN 50,000,000

Duration: 360 months

Not yet implemented

Source: www.ppp.gov.pl, Forum PPP 1(31) 2016, www.pppportal.pl

have been concluded in these sectors; however, the effectiveness of all proceedings initiated with respect to the 17 agreements concluded in this sector is relatively low (13.49\%), compared to telecommunication (50\%), water and sewerage $(48.28 \%)$ and energy efficiency $(38.89 \%)$, with average effectiveness in all sectors of $23.83 \%$. Five of these 112 agreements were contracts within the health sector, one of which has already been completed. The effectiveness in this sector was $11.76 \%$, considering the total amount of value of these four contracts which in the process of implementation. The largest contract amounts to more than PLN 138 million (approximately PLN 200 million in total investment) and thus 
qualifies as a large-project group (PLN 100-250 million). Among the other three, one is classified as "very small" (PLN 6.2 million), and two contracts belong to the microprojects group (below PLN 5 million). Market analysis has shown that micro-projects definitely dominated in all sectors (26.8\% of cases). Total projects worth less than PLN 50 million accounted for nearly $71.55 \%$ of all individual proceedings. Medium and larger projects accounted for only $28.45 \%$. The decisive superiority of micro and small projects indicates the fragmentation of the Polish PPP market, the reluctance to create larger joint projects, and the treatment of PPP as a specific, experimental way of carrying out public tasks.

It should be also stressed that the total of initiated proceedings in the health sector were 31 . But in 26 cases, tenders were canceled because no offer was received from the private sector. This shows the limitations of PPPs. The problems were that the expectations from the public sector were too big to be acceptable to the private partner (remuneration and risk). Additionally, the scale of investment required for infrastructure is far too large for private companies in Poland to provide. This demonstrates the very small market of private companies that first have money for investment and, second, would risk investing in a very unprofitable public health sector.

The report of the Polish Agency for Enterprise Development also includes information on the proposed investment projects for 2017 and 2018. At the end of April 2017, 143 proposals for PPPs were submitted, of which only nine are in the healthcare sector. All nine projects are based on infrastructure construction; the emergence of a new, or expansion of an existing building; and all are of the same model of PPP. The public entity will operate new facilities, and the private partner would benefit from the revenue from the expansion. Only two of the nine projects exceed the total investment estimated at more than 100 million, thus belonging to a large group of projects. All nine proposals are still at the stage before selecting a private partner.

As mentioned above, only five public-private partnerships so far are being continued in Poland in the healthcare sector. The first and only PPP that has already started to work (contract signed in 2009) is a partnership between a hospital in Jaworzno and the private partner Nefrolux. The aim of the partnership was to build a dialysis centre and nephrological clinic. The value of the investment is PLN 6.2 million. The length of the contract is set for 15 years, during which time the private partner manages, provides medical services, and benefits from the newly established facility. At the end of the contract period, the infrastructure, together with the equipment, will be transferred to a public hospital. At present, the partnership runs without difficulties, but in the early postconstruction period (few months) the dialysis centre was not able to provide medical service due to lack of an agreement with the National Health Fund. There are no data available that outline the financial benefits of this venture so far.
The Powiat Hospital in Żywiec is a leading example of PPPs in Poland. The project was supported in the form of financial and legal consultation during the private partner selection process, which was funded using resources from the Technical Assistance Program. The private partner chosen was InterHealth Canada. The PPP investment cost will be fully covered by the private partner (25\% own funds, $75 \%$ bank credit). The public partner will bring to the project the land for the new facility, with new road and hospital equipment. The private partner will build a new hospital and will manage it for an operational period determined as 30 years. The local government will monitor both the quality of the service and the efficiency of the facility. An agreement signed between a public and a private party also imposes an obligation to carry out external audits. InterHealth Canada is a leading healthcare organisation specializing in the development, commissioning, and management of healthcare facilities. The company was founded in 1994 and works in the United Kingdom, the United Arab Emirates, Kuwait, and the Turks and Caicos Islands. (http:// interhealthcanada.com/about-us/overview/) The contract in Poland was signed in September 2011. In 2015 the hospital was expected to accept the first patients. Unfortunately, that did not happen due to prolonged negotiations with the banks regarding the loan to finance the investment. The main reason was that contracts for medical services with the NFZ were established for too short periods of time. According to the new schedule, commissioning of the hospital will begin on 31 July 2018.

The other two implemented partnerships are still under construction.

The reason for the low interest in the PPP formula in healthcare could be alternative sources of capital for the entities. Hospital managers, as the main source of additional financing for investments, indicate EU funds, funds raised through the provision of commercial services, funds raised from the owners, ministerial projects, or other national and international funds (Magellan 2014b). Often the cost and difficulty of obtaining these funds may be lower than in the PPP formula.

Despite the low interest in the PPP formula in healthcare, public and private sector co-operation in this area has been developing in Poland for many years. The basis of cooperation is the fact that private healthcare providers can be financed from public funds. Health care areas such as Primary Care are largely privatized and at the same time paid for by the public. Another example may be dental care, which is almost $100 \%$ private, but to a small percentage funded by public funds. Specialized medical care is also often private, and may be paid using public funds.

In hospital care there has also been cooperation between the public and private sectors for a long time. There are several types of cooperation:

- Out-sourcing - for example for cleaning services, meals, medical analyses, laundry, etc. 
- Public hospital laboratories also carry out services for private entities

- Renting a part of a public hospital to a private entity and providing medical services via a private partner that are complementary to the services of a public partner.

- Joint shareholding by private and public partners in a hospital.

In Poland there are different types of ownership of hospitals: $100 \%$ private hospitals, hospitals operating as private and public joint-stock companies, and $100 \%$ public hospitals. Each of these can be financed from public funds. Unfortunately, the private medical insurance sector in Poland is underdeveloped, so this source of financing can not be considered sufficient in hospital care.

In the years 2001-2016, systematic commercialization and privatization of hospitals took place. Hospitals operating in the form of SPZOZs were transformed into capital companies (commercialization). They were owned by a public entity. After the commercialization process, there were possible sales of a part or all of the shares of the hospital to a private partner (privatization). By 2016, a private entity could acquire up to $100 \%$ of the shares. This form of involvement of the private sector in running hospitals could limit the interest in the PPP formula. Since July 2016, a private entity can acquire up to $49 \%$ of the company's shares. In addition, the prohibition of profit distribution in the form of dividends was introduced. This change in legislation may be an incentive for greater use of the PPP formula.

Over the course of recent years, a number of factors could contribute to an increase in the popularity of PPPs:

- The general government sector is indebted, so the Ministry of Finance and the Ministry of Development support the PPP formula for public sector investment. For this purpose, a special team in the Ministry of Development has been established for the development of PPPs; legislative changes have been introduced; PPP, as a source of funding; there is a series of training courses for local government officials dedicated to PPP.

- The current government and parliamentary majority are opposed to the privatization of hospitals. As a consequence, the PPP formula, which also includes the provision of services by the private partner, can be very attractive to implement (from the public partner's point of view), because it provides increased efficiency, does not increase the debt, and simultaneously the public partner has control over the medical services (Herbst et al. 2014).

- There is a possibility of a hybrid PPP, using European funds.

Polish government encourages PPP implementation by:

- organising PPP workshops for 1400 officials,
- building special PPP platforms and preparing drafts of PPP agreements,

- $\quad$ introducing some projects, which are aimed at popularization of PPP,

- organising PPP conferences.

\section{Discussion}

By analysing Polish PPP projects, all the factors affecting the failure of the ventures described by Kwak and co-authors (mentioned above) can be seen.

Central and local governments play a critical role in the development and management of PPPs. To encourage companies to invest in the health sector instead of other areas of the economy, the Polish government needs to provide incentives, conditions, and background which will attract investors. The basic factor must be the guarantee for the return of capital and earnings (Kwak et al. 2009).

The main factor inhibiting investment is the uncertainty associated with the National Health Fund. Against this background, a contractual health financing system in Poland appeared to be a significant impediment, assuming annual or triennial contracts. In comparison with the long-term involvement of the private partner in the implementation of the project, consideration should be given to modify the contracting of medical services performed by the PPP service providers with secure market competitiveness.

The second uncertainty associated with the National Health Fund, even with the contract being maintained, is the valuation of medical procedures. The lack of funding that would cover medical procedures would result in enormous debt for the hospital. In addition, the cost of annual charges for buildings constructed under PPP arrangements may be higher than the cost associated with hospitals built and run using conventional procedures. In that case, without changing funding, how should hospitals deal with higher costs if they can not cope with the current ones? One solution would be the development of commercial services within public hospitals. But crucially, the politicians are not in favour of such a solution. Moreover, there are many private medical centres on the Polish market which are much smaller units compared to hospitals, whose maintenance costs, and consequently price of services, are significantly lower than those offered in hospitals. In addition, there are no legal regulations that would protect the interests of public hospitals. Such regulations are widely used in other countries, and concern both the prices and the range of medical services performed in private centres. One such example is genetic testing, for which there is currently a huge demand and which does not have any legal regulation in Poland. The prices offered by private companies are much lower than those 
offered by public units, but the quality of tests is checked only in public centres.

Flexibility is a key factor which can affect all countries, but in particular a country such as Poland, which have long decision-making periods. The delivery of healthcare is changing rapidly in response to the new opportunities offered by new technology, shifting patterns of diseases, and rising public expectations (McKee et al. 2006). But the long-term contracts with PPPs are often specified in very great detail, and high penalties for changes are anticipated. This can be particularly severe when the private partner is responsible for the equipment needed to perform specific medical procedures. This lack of flexibility means that some hospitals are no longer up-to-date after a few years of contract life. In addition, the future cost of modifications (which is very difficult to predict in advance) falls on the public side.

Until now, the private sector was able to buy hospitals from public entities, so this may have caused less interest in the PPP formula.

The complexity of PPP contracts require the active participation not only of the Ministry of Health or Ministry of Finance, but also of local government, whose term of office is much shorter than the expected duration of the contract. What is more, the duration of the negotiations of the contract is usually longer than the term of office of the local governments (which lasts 4 years; from 2018 it will last 5 years).

The implementation of PPPs in the public hospital sector, despite some controversy, has positive implications and has come to be widely accepted. Numerous studies have evaluated the financial benefits of PPPs and showed that the average cost savings were up as much as 20\% (Sadeghi et al. 2016b; PwC 2010). The main advantages of PPPs should also be mentioned; they increase the value for money, help maximize the benefits of the public sector and achieving the social goal, allow hospitals to obtain alternative sources of capital, improve the quality of implemented projects; limit the public debt; transfer part of the responsibility to the private partner, transfer part of the management to the private partner, generate additional revenue from third parties, and enable the introduction of competition in sectors hitherto covered by the public monopoly (Kwak et al. 2009; Gajos 2014).

Funding This work was made possible by a grant from the National Science Centre (OPUS NCN 2015/17/B/NZ5/01357 to BAN).

\section{Compliance with ethical standards}

Conflict of interest The authors declare that they have no conflict of interest.

Ethical approval This article does not contain any studies with human participants or animals performed by any of the authors.

Informed consent Not applicable.
Open Access This article is distributed under the terms of the Creative Commons Attribution 4.0 International License (http:// creativecommons.org/licenses/by/4.0/), which permits unrestricted use, distribution, and reproduction in any medium, provided you give appropriate credit to the original author(s) and the source, provide a link to the Creative Commons license, and indicate if changes were made.

\section{References}

Deloitte (2016) Alumni reception 2016 global health care outlook battling costs while improving care. https://www2.deloitte.com

EIB (2012) PPPs and their financing in Europe: recent trends and EIB involvement. http://www.eib.org/attachments/efs/econ_note_2012_ ppp_and_financing_in_europe_en.pdf

Espigares JLN, Torres EH (2015) Public-private partnership as a new way to deliver healthcare services. University of Granada. https:// dialnet.unirioja.es/descarga/articulo/2942101.pdf

EXPH (Expert Panel on effective ways of investing in Health) (2014) Health and economic analysis for an evaluation of the publicprivate partnerships in health care delivery across Europe, 27 February 2014. https://ec.europa.eu

Forum PPP 1(31) 2016, https://www.ppp.gov.pl/Aktualnosci/Pozostale/ Documents/ForumPPP 2016_1_31.pdf

Gajos B (2014) Partnerstwo publiczno-prywatne. Aspekty bilansowopodatkowe. (en: Public-private partnership. Balance-tax aspects). Stowarzyszenie Księgowych w Polsce Zarząd Główny. Instytut Certyfikacji Zawodowej Księgowych. (en: Association of Accountants in Poland. Main Board. Institute for Professional Certification of Accountants), Warsaw

Gottwald M, Becker A, Bahr I, Mueller-Fahrnow A (2016) Public-private partnerships in lead discovery: overview and case studies. Arch Pharm (Weinheim) 349(9):692-697. https://doi.org/10.1002/ardp. 201600078

Granados Moreno P, Joly Y, Knoppers BM (2017) Public-private partnerships in cloud-computing services in the context of genomic research. Front Med (Lausanne) 4:3. https://doi.org/10.3389/fmed. 2017.00003

Hall D (2015) Why public-private partnerships don't work. The many advantages of the public alternative. Public Services International Research Unit University of Greenwich, UK. http://www.world-psi.org

Herbst I, Bogusz L, Kalecińska-Rossi J, Sarnacka A, Balicki M (2014) Partnerstwo publiczno-prywatne w szpitalach (en: public-private partnership in hospitals). Wolters Kluwer S.A, Warsaw

Herbst I, Jadach-Sepioło A (2012) Raport ze studiów przypadku PPP (en: Report on PPP case studies). Polska Agencja Rozwoju Przedsiębiorczości (en: Polish Agency for Enterprise Development), Warsaw

Hjertqvist J (2000) Swedish health-care reform: from public monopolies to market services. Materials from conference on the future of health care in Quebec. Montreal Economic Institute, Montreal http://www.iedm.org

Karawajczyk A, Orrling KM, de Vlieger JSB, Rijnders T, Tzalis D (2016) The European Lead Factory: a blueprint for public-private partnerships in early drug discovery. Front Med 3:75. https://doi.org/10. 3389/fmed.2016.00075

Kwak YH, Chih YY, Ibbs CV (2009) Towards a comprehensive understanding of public private partnerships for infrastructure development. Calif Manag Rev 51(2):51-78. https://doi.org/10.2307/ 41166480

Magellan SA (2014a) Sytuacja finansowa szpitali w Polsce (en: The financial situation of hospitals in Poland) http://www.magellansa.pl/portals/1/ files/raporty\%20rynkowe/raport sytuacja\%20finansowa\%20szpitali\% 20w\%20polsce.pdf, Accessed 2 January 2018 
Magellan SA (2014b) Sytuacja finansowa szpitali w Polsce. cz.2 (en: The financial situation of hospitals in Poland, part 2) http://www.magellansa. pl/Portals/1/Files/Raporty\%20rynkowe/Raport_Sytuacja\% 20finansowa\%20szpitali_cz.2.pdf, Accessed 3 January 2018

Mckee M, Edwards N, Atun R (2006) Public private partnerships for hospitals. Bull World Health Organ 84(11):890-896 www.who.int

Mitchell M (2003) An overview of public private partnerships in health. https://www.hsph.harvard.edu/ihsg/publications

PwC Health Research Institute (2010) Build and beyond: The (r)evolution of healthcare PPPs. www.pwc.com

Reijneveld SA (2012) Public-private partnerships in public health research: does it work and if yes, how? Eur J Pub Health 22(2):165166. https://doi.org/10.1093/eurpub/ckr187

Sadeghi A, Barati O, Bastani P, Jafari DD, Etemadian M (2016a) Strategies to develop and promote public-private partnerships (PPPs) in the provision of hospital services in Iran: a qualitative study. Electron Physician 8(4):2208-2214. https://doi.org/10. $19082 / 2208$

Sadeghi A, Barati O, Bastani P, Jafari DD, Etemadian M (2016b) Experiences of selected countries in the use of public-private partnership in hospital services provision. J Pak Med Assoc 66(11): 1401-1406 www.ncbi.nlm.nih.gov/pubmed/27812056

Taylor R, Blair S (2002) Public policy for the private sector; options for reform through public-private partnerships. The World Bank's Private Sector and Infrastructure Network; Note Number 241. http://siteresources.worldbank.org/EXTFINANCIALSECTOR/ Resources/282884-1303327122200/241 Taylo-010802.pdf

Wawrzyniak M (2016) Co się zmienia, a co się musi zmienić w otoczeniu prawnym PPP? (en: What is changing and what needs to change in the PPP legal environment?), Forum PPP. Magazyn Inwestycji Publicznych (en: Public Investment Magazine), 3 (33) http:// forumppp.pl/Forum\%20PPP/2016_3_33/2016_3_33_calosc.pdf 